\title{
Comparative Proteome Analysis of Porcine Longissimus dorsi on the Basis of $\mathrm{pH} 24$ of Post-mortem Muscle
}

\author{
Juhyun Nam ${ }^{1}$, Dong-Gi Lee ${ }^{1}$, Joseph Kwon ${ }^{2}$, Chi-Won Choi ${ }^{1}$, Seong Hwa Park ${ }^{2}$, Sang-Oh Kwon ${ }^{1,3}$, Jong Hyun Jung ${ }^{5}$, \\ Hwa Choon Park ${ }^{5}$, Beom Young Park ${ }^{6}$, Ik Soon Jang ${ }^{1}$, Woo Young Bang ${ }^{4}$, Chul Wook Kim ${ }^{4}$ \& Jong-Soon Choi ${ }^{1,3}$ \\ ${ }^{1}$ Division of Life Science, Korea Basic Science Institute, Daejeon, Korea \\ ${ }^{2}$ Gwangju Center, Korea Basic Science Institute, Gwangju, Korea \\ ${ }^{3}$ Graduate School of Science and Technology, Chungnam National University, Daejeon, Korea \\ ${ }^{4}$ Swine Science \& Technology Center, Gyeongnam National University of Science and Technology, Jinju, Korea \\ ${ }^{5}$ Da-San-Jong-Don Co. Ltd., Namwon, Korea \\ ${ }^{6}$ National Institute of Animal Science, Suwon, Korea \\ Correspondence: Woo Young Bang, Swine Science \& Technology Center, Gyeongnam National University of \\ Science and Technology (GNTECH), Jinju 660-758, Korea. Tel: 82-55-751-3688. E-mai: wybang@gntech.ac.kr \\ / ChulWook Kim, Swine Science \& Technology Center, Gyeongnam National University of Science and \\ Technology (GNTECH), Jinju 660-758, Korea. Tel: 82-55-751-3281. E-mail: cwkim@gntech.ac.kr / Jong-Soon \\ Choi, Division of Life Science, Korea Basic Science Institute, Daejeon305-333, Korea. Graduate School of \\ Science and Technology, Chungnam National University, Daejeon 660-758, Korea. Tel: 82-42-865-3428. E-mail: \\ jschoi@kbsi.re.kr
}

Received: April 6, 2012 Accepted: April 23, 2012 Online Published: July 26, 2012

doi:10.5539/jas.v4n9p48 URL: http://dx.doi.org/10.5539/jas.v4n9p48

The research is financed bygrants from the Priority Research Centers Program (2011-0022965) and Basic Science Research Program (2012-0008319) through the National Research Foundation of Korea (NRF) funded by the Ministry of Education, Science and Technology, the BioGreen 21 Program (20080401034059) of Rural Development Administration of Korea, and the Technology Development Program for Agriculture and Forestry (107091-5), Ministry for Food, Agriculture, Forestry and Fisheries, Republic of Korea. It was also financially supported by a Korea Basic Science Institute NAP grant (T32780) to J.S. Choi.

\begin{abstract}
To identify proteins contributing to meat quality, a comparative shotgun proteomic profiling of Berkshire longissimus dorsi muscles was conducted in high $\mathrm{pH}$ group $(\mathrm{HpHG})$ and low $\mathrm{pH}$ group (LpHG) based on 24 hour post-mortem $\mathrm{pH}$. Triplicate liquid chromatography-tandem mass spectrometry analysis identified a total of 208 and 204 proteins in the $\mathrm{HpHG}$ and LpHG, respectively. A total of 128 proteins were classified on the basis of molecular function, cellular components, and biological process by gene ontology analysis, of which 13 and 21 proteins were exclusively found in the $\mathrm{HpHG}$ and $\mathrm{LpHG}$, respectively. A total of 15 proteins, of which 6 proteins belonged to the $\mathrm{LpHG}$ and 2 to the $\mathrm{HpHG}$, were assigned to the Sus scrofa genomic database. The dominant expressions of Igc, Prep, Ldhb, and Aco 2 were identified in the LpHG by shotgun proteomic analysis, and confirmed by reverse transcriptase-mediated polymerase chain reaction analysis. These protein markers are suitable for determining meat quality.
\end{abstract}

Keywords: meat quality, longissimus dorsi muscle, protein biomarker, shotgun proteomics

\section{Introduction}

Porcine meat quality depends on meat color, hardness and the water and fat contents of muscle tissues (Hocquette et al., 2005). In general, the intramuscular fat content and tenderness of meat can affect its taste. Thus, the relation of these factors to the marbling score and Warner-Bratzler shear force is considered to be one of the most important factors in meat production and marketing (Kim et al., 2008). In addition to direct meat-quality factors, the water-holding capacity (WHC) of the muscle affects meat production, and the WHC is closely related to the post-mortem biochemical process (McIntosh, Berman, \& Kench, 1977). Recently, traits correlated 
with expression QTL (quantitative trait loci) analysis identified several biochemical processes involved in live skeletal porcine muscle and meat quality, including oxidative phosphorylation, mitochondrial pathways, and transporter activity (Ponsuksili et al., 2008). WHC correlates negatively with drip loss, which is primarily caused by the shrinkage of myofibrils due to a reduction in the intramuscular energy reservoir, $\mathrm{pH}$, and temperature (Offer \& Knight, 1988). The ultimate $\mathrm{pH}$ of post-mortem muscle, corresponding to the $\mathrm{pH}\left(\mathrm{pH}_{24 \mathrm{hr}}\right) 24$ hours post-slaughter, can be simply determined as a meat-quality trait that is closely related to WHC (Warner, Kauffman, \& Greaser, 1997). Fast post-mortem degradation of glycogen leads to a rapid decline in muscular $\mathrm{pH}$, resulting in poor meat quality (known as acid meat), whereas slow degradation of intramuscular glycogen results in a relatively slower decline in pH, suggesting good meat quality (Le Roy, Naveau, Elsen, \& Sellier, 1990). Thus, high $\mathrm{pH}$ group $(\mathrm{HpHG})$ and low $\mathrm{pH}$ group $(\mathrm{LpHG})$ were classified on the basis of muscular $\mathrm{pH}_{24 h r}$ after slaughter.

Proteomics allows the identification of potential protein markers involved in meat-quality traits. Recently, two-dimensional gel electrophoresis (2-DE) was used to identify differentially expressed proteins in Meishan and Large White pigs (Xu et al., 2009). The identification of proteins potentially related to a high level of marbling was attempted for the purpose of genetic design, using 2-DE-based proteomics (Liu et al., 2009) and the natural variations of synthetic lines from Duroc, Hampshire and Large White pigs. We performed large-scale proteomic profiling of longissimus dorsi muscle (LDM) from HpHG and LpHG of Berkshire pigs using a gel-based shotgun proteomic approach (Wang et al., 2004). In the present study, in order to identification of meat quality related proteins, high $\mathrm{pH}$ and low $\mathrm{pH}$ groups LDM of porcine 24 hours post-slaughter were analyzed by 1-DE/LC-MS/MS. The possible roles of the identified proteins as potential protein markers for meat quality investigation are discussed.

\section{Method}

\subsection{Animals and Longissimus Dorsi Muscle Preparation}

The pigs originated from a population of 102 male Berkshires $(80 \sim 100 \mathrm{~kg}, 120 \mathrm{~d}$ old $)$ provided by Da-San-Jong-Don Co. Ltd. (Namwon-city, Korea). Pigs were slaughtered following standard slaughtering procedures. A longissimus dorsi muscle (LDM) sample of approximately 10 gram was collected at the $5^{\text {th }}$ thoracic vertebrate shortly after slaughter and immediately frozen in liquid nitrogen prior to shotgun proteomic analysis.

\subsection{Physical Measurement of Meat Quality}

After slaughtering, the $\mathrm{pH}$ values $\left(\mathrm{pH}_{45 \min }\right.$ and $\left.\mathrm{pH}_{24 \mathrm{hr}}\right)$ of the $\mathrm{LDM}$ samples at the $5^{\text {th }}$ thoracic vertebrate were determined in triplicate, using a portable needle-tipped electrode ( $\mathrm{pH}-\mathrm{K} 21$; NWKbinarGmbH, Landsberg, Germany). The color ( $L$, lightness; $a$, redness; $b$, yellowness) of each LDM surface was recorded after a 30-min blooming at $1{ }^{\circ} \mathrm{C}$ using a Minolta Chromameter (CR400; Minolta, Japan). The WHC of the LDM samples was determined as described previously (Kristensen \& Purslow, 2001). The fat and collagen contents (\%) of the LDM samples were determined using a Foodscan (Food Scan ${ }^{\mathrm{TM}}$ Lab, type 78810; Foss Co., Denmark) (Anderson et al., 2007). Warner-Bratzler shear force, drip loss, and cooking loss were measured as previously described (Kauffman, Eikelenboom, Van der Wal, Engel, \& Zaar, 1986; Wheeler, Shackelford, \& Koohmaraie, 2000).

\subsection{Extraction of Muscular Proteins}

Protein samples were collected from three male Berkshire pigs randomly chosen from the upper $10 \% \mathrm{pH}_{24 h \mathrm{r}}(\mathrm{pH}$ $5.73 \sim 6.17,10$ pigs) and lower $10 \% \mathrm{pH}_{24 \mathrm{hr}}(\mathrm{pH} 5.37 \sim 5.47,10$ pigs) of the total group of 102 pigs. Porcine LDM proteins were prepared by using a previously described method (Lametsch \& Bendixen, 2001). In brief, the 1.5-gram LDM tissue samples were ground with a mortar in liquid nitrogen, and the proteins were extracted with extraction buffer containing $0.3 \%$ (w/v) sodium dodecyl sulfate (SDS), $0.2 \mathrm{M}$ dithiothreitol, and $1 \mathrm{M}$ Tris-HCl ( $\mathrm{pH} 8$ ). The crude extracts of individual LDM samples were centrifuged at $14,000 \mathrm{rpm}$ for $20 \mathrm{~min}$ at $4^{\circ} \mathrm{C}$. The supernatant was treated with 20 kilounits of DNase and 7.5 kilounits of RNase and centrifuged at 14,000 rpm for $30 \mathrm{~min}$ to obtain the solubilized supernatant. The final supernatant was precipitated by incubation with $10 \%(\mathrm{w} / \mathrm{v})$ trichloroacetic acid at room temperature for $1 \mathrm{hr}$. The mixture was centrifuged at 14,000 rpm for $30 \mathrm{~min}$ to obtain the precipitate and subsequently washed three times with $100 \%(\mathrm{v} / \mathrm{v})$ acetone. The precipitate was freeze-dried by Speed Vacuum (SC110A; GMI Inc., MI) and dissolved with $20 \mathrm{mM}$ Tris-HCl buffer (pH 8) and adjusted to a final concentration of $1 \mu \mathrm{g} / \mu \mathrm{l}$, as measured by the Bradford protein assay.

\subsection{One-dimensional Gel-based Proteomics Coupled with Liquid Chromatographytandem Mass Spectrometry}

For the shotgun proteomic analysis based on SDS-polyacrylamide gel electrophoresis separation (SDS-PAGE) and liquid chromatography-tandem mass spectrometry (LC-MS/MS), the LDM proteins ( $15 \mu \mathrm{g} / \mathrm{per}$ lane) were loaded on $12 \%$ SDS-polyacrylamide gel $(10 \times 8 \mathrm{~cm})$. After electrophoresis, the gels were stained with 
Coomassie Brilliant Blue R-250 and then separately cut into 8 slices according to the stained gel band intensity, as shown in Figure 1. Each gel slice was transferred into a new Eppendorf tube. In-gel tryptic digestion was conducted as previously reported (Wang, et al., 2004). The tryptic digests were extracted with $0.02 \%(\mathrm{v} / \mathrm{v})$ formic acid in $0.5 \%(\mathrm{v} / \mathrm{v})$ acetic acid. The extracts were freeze-dried for later LC-MS analysis. The $10 \mu \mathrm{l}$ peptide samples were concentrated on an MGU30- $\mathrm{C}_{18}$ trapping column (LC Packings, Dionex, Sunnyvale, CA) and analyzed using the nano-column $\left(10 \mathrm{~cm} \times 75 \mathrm{~mm}\right.$ internal diameter, $\mathrm{C}_{18}$ reversed-phase column; Proxeon, Odense, Denmark) at a flow rate of $120 \mathrm{nl} / \mathrm{min}$. The peptides were eluted from the column by applying gradient $(0-65 \%, \mathrm{v} / \mathrm{v})$ acetonitrile for $80 \mathrm{~min}$ at a constant flow rate. All MS and MS/MS spectra were obtained in a data-dependent mode by the electrospray ionization ion trap MS (LCQ-Deca XP; Thermo, Waltham, MA). MS analysis was performed in triplicate using a different batch of samples.

\subsection{Bioinformatic Analysis}

For protein identification, MS/MS spectra were searched using an internal Mascot server (version 2.2; Matrix Sciences Inc, London, UK) against a SwissProt 57.5 mammalian database. Search parameters allowed for methionine oxidation $(+16 \mathrm{Da})$, cysteine carbamidomethylation $(+57)$, and one missed trypsin cleavage within 1.5 Da for peptide tolerance and within $1.5 \mathrm{Da}$ for fragmented peptide. The False discovery rate (FDR), up to $10 \%$, was permitted to validate the final proteomic data. The exponentially modified protein abundance index (emPAI) values of identified proteins at the specific group were recorded by the triplicate LC-run, and their abundance was semi-quantified to present the average mol\% using statistical analysis by Student's $t$-test, as described previously (Ishihama et al., 2005). The gene ontology of the identified proteins was searched using QuickGO (http://www.ebi.ac.uk). Each histogram and box plot was calculated using the statistical package R program.

\subsection{Reverse Transcriptase-Mediated PCR Analysis}

Total RNA in LDM was isolated with TriZol (Invitrogen, Seoul, Korea) and RNase-free DNase (Promega, Seoul, Korea) according to the manufacturer's protocol. The RNA was quantified with a Nanodrop.The complementary DNA (cDNA) was synthesized in a $20-\mu$ l volume, with $5 \mu \mathrm{g}$ total RNA as a template, using oligo-dT primers and reverse transcriptase (Invitrogen, Seoul, Korea). The specific primers were for igc (sense: $5^{\prime}$-GCC ACC CTG GTG TGT CTA AT-3', antisense: 5'-GCG TCA CTG TCT TCT CCA CA-3'), prep (sense: 5'-GAT GGC TCT CAT CCT GCC TT-3', antisense: 5'-ACC ACC TTT GTG CCA CGT CT-3'), ldhb (sense: 5'-CAC GGA AGC TTG TTC CTT CA-3', antisense: 5'-CAT TGA CGT TCC TCT GCA CC-3'), and aco2 (sense: 5'-GCT GGA CCT CAC CCA AAG AT-3', antisense: $5^{\prime}$-ATG TTG CAG ATT GTC GCC AT-3'). The primers for $\beta$-actin (sense: 5'-AGG TCA TCA CTA TTG GCA AC-3'; antisense: 5'-ACT CAT CGT ACT CCT GCT TG-3') were used as an internal control. PCR was performed using $1 \mu \mathrm{l}$ of synthesized cDNA from four individual samples from the HPHG and LPHG and from 5 pmol of each primer set in a premixed PCR reaction kit (Bioneer, Daejeon, Korea) in a GeneAmp ${ }^{\circledR}$ PCR system 9700 (Applied Biosystems, CA). PCR amplification was carried out according to the following procedure: initial denaturation at $94^{\circ} \mathrm{C}$ for $5 \mathrm{~min}$, followed by 30 cycles (28 cycles in case of $i g c$ and $l d h b)$ at $94^{\circ} \mathrm{C}$ for $15 \mathrm{sec}, 55^{\circ} \mathrm{C}$ for $15 \mathrm{sec}\left(58^{\circ} \mathrm{C}\right.$ in case of prep), and $72^{\circ} \mathrm{C}$ for $20 \mathrm{sec}$ and the extension at $72^{\circ} \mathrm{C}$ for $5 \mathrm{~min}$. The ethidium bromide-stained PCR products were electrophoresed in $2 \%$ agarose gel. The statistical significance of relative abundance was assessed using a paired Student's $t$-test at $P<0.001$.

\section{Results}

\subsection{Comparison of Meat-quality Traits between the $H p H G$ and $L p H G$}

Post-mortem $\mathrm{LDM} \mathrm{pH}_{24 \mathrm{hr}}$ values were measured from 102 male Berkshire pigs representing the highest $10 \%$ group (HpHG) and the lowest $10 \%$ group (LpHG). The overall distribution of post-mortem $\mathrm{LDM} \mathrm{pH}_{24 \mathrm{hr}}$ values is shown in Supplementary Figure 1. The physical traits of meat quality were compared, as shown in Table 1 . The initial difference in $\mathrm{pH}_{45}$ min after the onset of slaughter was not significant. However, the meat from the HpHG was slightly brighter, less reddish $(P<0.05)$ and less yellowish on the surface than that of the LpHG. The WHC of the HpHG was higher than that of the LpHG, but the difference was not significant. Drip loss, however, was significantly lower for the HPHG than for the LpHG $(P<0.05)$. This result coincides with the results of previous reports showing that similar to the drip loss factor, the extent of the $\mathrm{pH}$ decrease is an indicator of the meat quality (Fischer, 2007).

\subsection{Differentially Expressed Proteins of LDM from the $H p H G$ and $L p H G$}

To identify the differentially expressed proteins from the HpHG and LpHG, the soluble proteins from the meat of both groups were extracted and separated by SDS-PAGE. On the basis of molecular weight and band intensity, the sliced gels were excised, digested with trypsin, followed by LC-MS/MS analysis. This shotgun proteomic 
method is advantageous for identifying the proteome at a large scale - over 2-DE/MALDI-TOF MS (Wang, et al., 2004). Results obtained from triplicate analyses showed a total of 128 proteins both HpHG and LpHG. The identified proteins by at least two hits were analyzed for the specific proteins exclusively expressed in each group. As a result, 13 and 21 proteins were exclusively found in the $\mathrm{HpHG}$ and LpHG, respectively, whereas 94 proteins were commonly found in both groups (Figure 2). A total of 128 proteins were classified on the basis of molecular function, cellular components, and biological process by gene ontology analysis (Figure 3).

\subsubsection{Validation of Protein Biomarkers Responsible for Meat Quality}

LpHG-specific proteins (Ldhb and Prep) and LpHG-abundant proteins (Igc and Aco2), identified by LC-MS/MS based shotgun proteomics, were chosen for the biochemical validation to determine whether these proteins are indicators of meat quality, as based on post-slaughter $\mathrm{pH}_{24 \mathrm{hr}}$. The relative expressions of the four targeted genes were determined by using reverse transcriptase-mediated PCR analysis. As shown in Figure 4, randomly selected muscle samples from the HpHG or LpHG were used for a comparative analysis of mRNA abundance. The expression levels of igc, prep, ldhb, and aco2 were dramatically higher in the $\mathrm{LpHG}$ than in the HpHG, thus showing good agreement with mRNA and protein levels.

Table 1. Characteristics of physical meat traits from two Berkshire male meat quality groups

\begin{tabular}{|c|c|c|c|}
\hline \multicolumn{2}{|c|}{ Component } & Low pH Group & High pH Group \\
\hline \multicolumn{2}{|l|}{ Sample number } & 10 & 10 \\
\hline \multicolumn{2}{|l|}{$\mathrm{pH} 45 \mathrm{~min}$} & $6.05 \pm 0.23$ & $6.12 \pm 0.26$ \\
\hline \multicolumn{2}{|l|}{$\mathrm{pH} 24 \mathrm{hrs}$} & $5.43 \pm 0.04$ & $5.86 \pm 0.14^{b}$ \\
\hline \multirow{3}{*}{ CIE } & $L$ & $50.36 \pm 3.13$ & $47.00 \pm 4.31$ \\
\hline & $a$ & $6.29 \pm 0.87$ & $5.42 \pm 0.83^{\mathrm{a}}$ \\
\hline & $b$ & $2.58 \pm 0.95$ & $1.78 \pm 0.99$ \\
\hline \multicolumn{2}{|c|}{ Water Holding Capacity (\%) } & $55.62 \pm 1.80$ & $56.21 \pm 1.33$ \\
\hline \multicolumn{2}{|c|}{ Intramuscular fat contents $(\%)$} & $2.29 \pm 1.23$ & $1.70 \pm 0.74$ \\
\hline \multicolumn{2}{|c|}{ Collagen contents $(\%)$} & $0.89 \pm 0.10$ & $0.86 \pm 0.09$ \\
\hline \multicolumn{2}{|c|}{ Warner-Bratzler shear force $\left(\mathrm{kg} / 0.5 \mathrm{in}^{2}\right)$} & $3.26 \pm 0.53$ & $3.35 \pm 0.74$ \\
\hline \multicolumn{2}{|l|}{ Drip loss $(\%)$} & $6.81 \pm 1.39$ & $4.57 \pm 2.48^{\mathrm{a}}$ \\
\hline \multicolumn{2}{|l|}{ Cooking loss $(\%)$} & $28.07 \pm 3.25$ & $24.62 \pm 5.02$ \\
\hline
\end{tabular}

${ }^{\mathrm{a}} P<0.05 ;{ }^{b} P<0.01$

Table 2. Identified proteins from high and low meat quality groups

\begin{tabular}{|c|c|c|c|c|c|c|}
\hline \multirow{2}{*}{ Acc No. } & \multirow{2}{*}{ Protein name } & \multirow{2}{*}{$\begin{array}{l}\text { Gene } \\
\text { Name }\end{array}$} & \multirow{2}{*}{ Organism } & \multicolumn{2}{|c|}{ Average $\mathrm{Mol} \%{ }^{\mathrm{a}}$} & \multirow{2}{*}{$P$ value ${ }^{b}$} \\
\hline & & & & $\mathrm{HpHG}$ & LpHG & \\
\hline Q00004 & Signal recognition particle $68 \mathrm{kDa}$ protein & SRP68 & Canis familiaris & 0.07 & N.D. ${ }^{c}$ & 0.000 \\
\hline Q8K2B3 & $\begin{array}{l}\text { Succinate dehydrogenase [ubiquinone] } \\
\text { flavoprotein subunit, mitochondrial }\end{array}$ & Sdha & Mus musculus & 0.07 & N.D. & 0.000 \\
\hline P50828 & Hemopexin & HPX & Sus scrofa & 0.09 & N.D. & 0.000 \\
\hline Q8BZF8 & Phosphoglucomutase-like protein 5 & Pgm5 & Mus musculus & 0.08 & N.D. & 0.000 \\
\hline Q2KPA3 & Hemoglobin subunit beta & HBB & Scapanus orarius & 0.44 & N.D. & 0.026 \\
\hline A2ASS6 & Titin & Ttn & Mus musculus & 0.00 & N.D. & $0.032-$ \\
\hline Q7TQ48 & Sarcalumenin & Srl & Mus musculus & 0.09 & 0.03 & 0.046 \\
\hline Q2KJJ9 & $\begin{array}{l}\text { Fructose-1,6-bisphosphatase } \\
\text { isozyme } 2\end{array}$ & FBP2 & Bos taurus & 0.58 & 0.29 & 0.024 \\
\hline O18751 & Glycogen phosphorylase, muscle form & PYGM & Ovis aries & 5.37 & 3.06 & 0.006 \\
\hline Q3ZC07 & Actin, alpha cardiac muscle 1 & ACTC1 & Bos taurus & 0.04 & 0.24 & 0.017 \\
\hline Q2HYU2 & 6-phosphofructokinase, muscle type & PFKM & Sus scrofa & 0.02 & 0.49 & 0.000 \\
\hline P23109 & AMP deaminase 1 & AMPD1 & Homo sapiens & N.D. & 0.11 & 0.000 \\
\hline Q75NG9 & Troponin $\mathrm{T}$, fast skeletal muscle & TNNT3 & Sus scrofa & N.D. & 0.15 & 0.000 \\
\hline P00336 & L-lactate dehydrogenase $\mathrm{B}$ chain & LDHB & Sus scrofa & N.D. & 0.79 & 0.002 \\
\hline Q5S1U1 & Heat shock protein beta- 1 & HSPB1 & Sus scrofa & N.D. & 1.03 & 0.031 \\
\hline Q8VHX6 & Filamin-C & Flnc & Mus musculus & N.D. & 0.03 & 0.046 \\
\hline
\end{tabular}

HpHG, high pH24 group; LpHG, low pH24 group

${ }^{\text {a }}$ Average Mol\% is based on emPAI that is calculated by MASCOT v. 2.2.

${ }^{b} \mathrm{P}$ value was obtained by Student $t$-test with Mol\% of each LC-MS/MS run.

${ }^{c}$ Not detectable 
Table 3. Meat quality-determining protein biomarker candidates assigned to Sus scrofa

\begin{tabular}{|c|c|c|c|c|c|c|}
\hline \multirow{2}{*}{ Acc No. } & \multirow{2}{*}{ Protein name } & \multirow{2}{*}{$\begin{array}{l}\text { Gene } \\
\text { Name }\end{array}$} & \multicolumn{2}{|c|}{ Average $\mathrm{Mol} \%{ }^{a}$} & \multirow{2}{*}{$P$ value } & \multirow{2}{*}{ Ratio $^{c}$} \\
\hline & & & $\mathrm{HpHG}^{\mathrm{b}}$ & $\mathrm{LpHG}^{\mathrm{b}}$ & & \\
\hline Q75NG9 & Troponin T, fast skeletal muscle & TNNT3 & N.D. ${ }^{d}$ & 0.15 & 0.000 & LpHG \\
\hline P00336 & L-lactate dehydrogenase $\mathrm{B}$ chain & LDHB & N.D. & 0.79 & 0.002 & LpHG \\
\hline Q5S1U1 & Heat shock protein beta-1 & HSPB1 & N.D. & 1.03 & 0.031 & LpHG \\
\hline P23687 & Prolyl endopeptidase & PREP & N.D. & 0.04 & 0.092 & LpHG \\
\hline Q9TSX9 & Peroxiredoxin-6 & PRDX6 & N.D. & 0.13 & 0.092 & LpHG \\
\hline Q7M2W6 & Alpha-crystallin B chain & CRYAB & N.D. & 0.54 & 0.163 & LpHG \\
\hline Q2HYU2 & 6-phosphofructokinase, muscle type & PFKM & 0.02 & 0.49 & 0.000 & 0.04 \\
\hline P01846 & Ig lambda chain $\mathrm{C}$ region & IGC & 0.17 & 0.48 & 0.098 & 0.34 \\
\hline Q2XQV4 & Aldehyde dehydrogenase, mitochondrial & ALDH2 & 0.06 & 0.11 & 0.221 & 0.50 \\
\hline Q9GJT2 & S-formylglutathione hydrolase & ESD & 0.06 & 0.11 & 0.268 & 0.51 \\
\hline P16276 & Aconitate hydratase, mitochondrial & $\mathrm{ACO} 2$ & 0.12 & 0.17 & 0.130 & 0.69 \\
\hline P00339 & L-lactate dehydrogenase A chain & LDHA & 3.48 & 2.49 & 0.108 & 1.40 \\
\hline P52552 & Peroxiredoxin-2 (Fragment) & PRDX2 & 0.58 & 0.40 & 0.334 & 1.44 \\
\hline P50828 & Hemopexin & HPX & 0.09 & N.D. & 0.000 & HpHG \\
\hline P00346 & Malate dehydrogenase, mitochondrial & MDH2 & 0.09 & N.D. & 0.092 & HpHG \\
\hline
\end{tabular}

\section{Discussion}

The decreased rate of $\mathrm{pH}$ decline after slaughter reflects a slightly high WHC and a low drip loss, which are influenced by biochemical processes such as ultimate muscle $\mathrm{pH}$, protein denaturation, and intramuscular sarcomere length (Offer \& Knight, 1988). The Rendement Napole $(R N)$ gene affects the glycogen content of muscle and a mutation at the $R N$ gene results in poor meat quality due to post-mortem degradation of glycogen, which leads to a lowering of muscle pH, associated with a sub-optimal WHC (Le Roy, et al., 1990; Milan et al., 2000).

When categorized by molecular function, the proteins identified by LC-MS/MS analysis functioned in enzyme regulation (49\%), extracellular space (33\%), macromolecular complex (10\%), membrane-bound organelles $(3 \%)$. When categorized by cellular process, the high-ranking groups were protein complex $(28 \%)$, rhythmic process $(17 \%)$, structural molecular activity $(12 \%)$, response to stimulus $(11 \%)$, metabolic process $(10 \%)$. When categorized by biological process, the proteins were identified as belonging to the following classes: metabolic process $(46 \%)$, multi-cellular organism process $(15 \%)$, response to stimuli $(14 \%)$, and others $(25 \%)$ (Figure 3 ). The differentially expressed proteins identified from either the HpHG or LpHG are shown in Table 2; the proteome data from triplicate LC-runs were considered significant if the $P$ value is less than 0.05 . Due to the incomplete genomic database for pigs, all of the proteomic data were not assigned to Sus scrofa. Sixteen proteins listed in Table 3 belonged to $S$. scrofa exactly, for which the semi-quantitative abundance is presented as the average mol\% based on the exponentially modified protein abundance index (PAI), as described previously (Ishihama, et al., 2005). In particular, 12 proteins were increased in LpHG, whereas 4 proteins increased in HpHG.

Theporcine immunoglobulin lambda gene (igl) was mapped on chromosome 14q17-q21 by fluorescence in situ hybridization (Slingsby, Dyson, Morley, Walport, \& Simpson, 1996). The expression of Iglwas more highly up-regulated in the skeletal proteome of male pigs than that of female pigs (Hakimov et al., 2009). Our finding was similar to that reported by Medina et al. (2000)(Medina, Strasser, \& Kincade, 2000), who showed that the expression of $i g c$ was up-regulated in murine males, resulting in the suppressed production of new B-lineage precursor lymphocytes, caused by different exposures to estrogen.

Propyl endopeptidase (Prep) is a key player in the degradation of peptides and neuropeptides, although its biological function is not known. Prep, however, is widely distributed across mammalian tissues, plants and bacteria (Cunningham \& O'Connor, 1997). Because the protein level of Prep, as a proline-specific peptidase, is more highly expressed in LpHG than in HpHG, Prep is presumably involved in the retarded degradation of 
muscle proteins in HpHG. Up-regulation of lactate dehydrogenase in LpHG suggests higher oxidative muscle metabolism, which in turn is related to a lower $\mathrm{pH}_{24 \mathrm{hr}}$. This phenomenon was likely observed in previous reports (Bee, Guex, \& Herzog, 2004; Gondret \& Lebret, 2002). Aconitate hydratase functions to catalyze the isomerization of the mutual conversion of citrate tocis-aconitate in the tricarboxylic acid cycle. In rats, under conditions of food-deprivation, the activity of aconitate dehydratase in rat hepatocytes is known to increase (Eprintsev, Semenova, \& Popov, 2002). This suggests that the mobilization of the reserved nutrients to supply energy-consuming organs, such as skeletal muscle, results in the activation of citric acid-catalyzing enzymes. Likewise, the increased expression level of aconitate dehydratase in LpHG suggests that it is related to the higher energy conversion that occurs to ensure gluconeogenesis, due to the low capacity of direct glucose utilization.

In conclusion, SDS-PAGE was used to extract and separate LDM proteins from the two meat-quality groups ( $\mathrm{HpHG}$ and $\mathrm{LpHG}$ ), based on muscular $\mathrm{pH}_{24 h \mathrm{r}}$ after slaughter. This extraction and separation was followed by protein analysis using LC-MS/MS. Shotgun proteomic analysis by SDS-PAGE/LC-MS/MS identified a total of 128 proteins. Most of the proteins were grouped in the categories "metabolic process" and "structural" proteins. Of the 16 proteins assigned to $S$. scrofa, those expressed either abundantly or exclusively in the LpHG were chosen for analysis of mRNA levels using RT-PCR. Taken together with the proteomic analysis, the expression levels of igc, prep, ldhb, and aco2 were higher in the LpHG. The result of the presentinvestigation is supported by the previously established concept that mRNA expression patterns are able to represent with protein expression levels (Ahsan, et al., 2008). These results provided additional evidence of the identified proteins, as well as indicating that these proteins are highly related meat quality among high and low $\mathrm{pH}$ groups. Thus, the meat quality-determining proteins in Berkshire pigs can be easily used in the agricultural industry as a marker for meat quality.

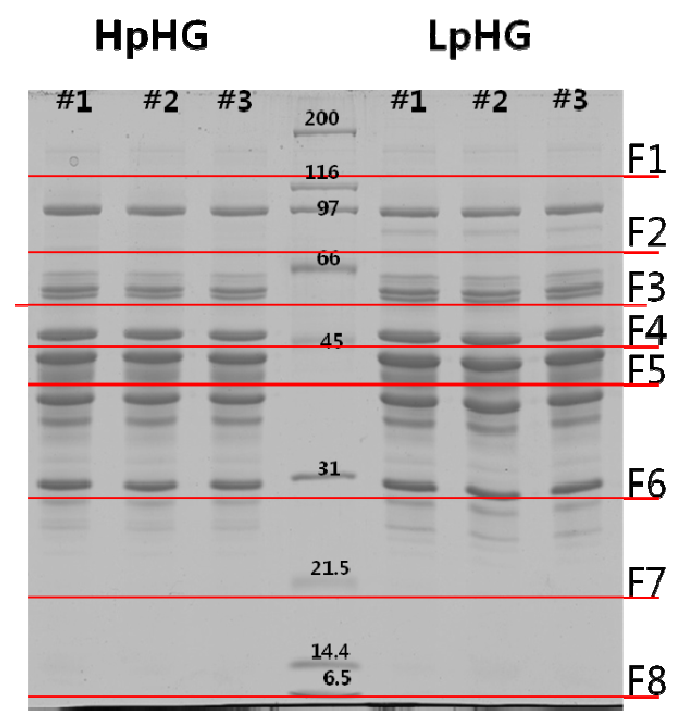

Figure 1. Coomassie-stained SDS-polyacrylamide gel of porcine LDM proteins from HpHG and LpHG. Central lane, molecular weight markers

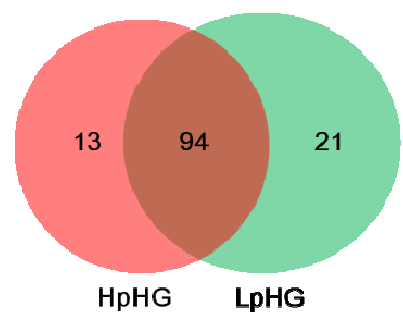

Figure 2. Venn diagrams of identified proteins from high $\mathrm{pH}$ group (HpHG) and low $\mathrm{pH}$ group (LpHG) samples by shotgun proteomic analysis. Proteins separated on the SDS-polyacrylamide gel, in-gel digested, following

LC-MS/MS analysis in which proteins were assigned to SwissProt 57.5 mammalian database-Exclusively found protein number with at least two or more hits in HpHG or LpHG samples were shown 
(A)

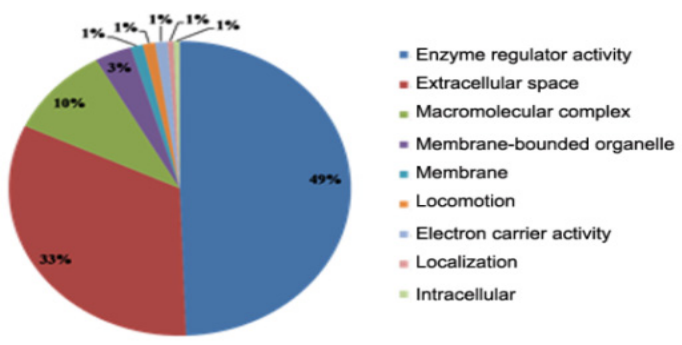

(B)

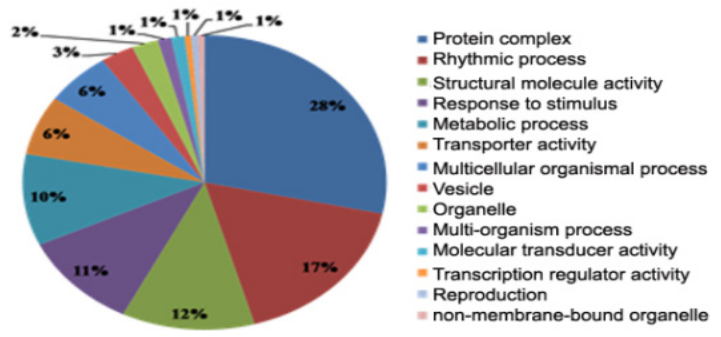

(C)

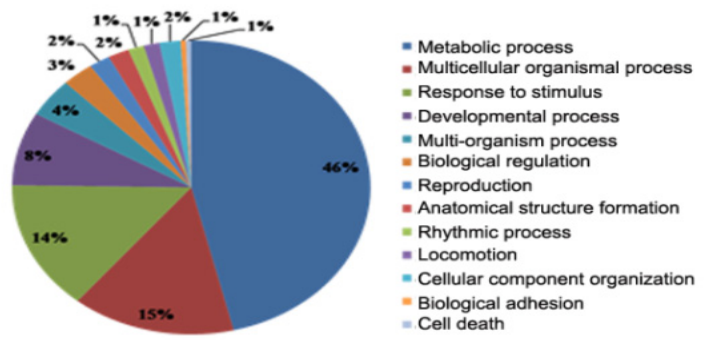

Figure 3. Gene ontology of a total of 128 identified proteins classified according to molecular function (A), cellular components (B), and biological process (C)

(A)

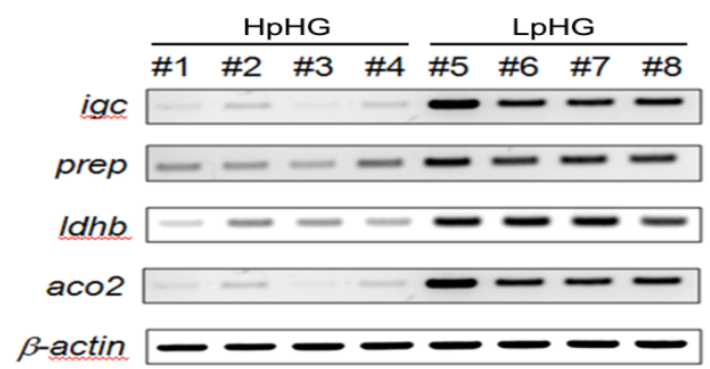

(B)
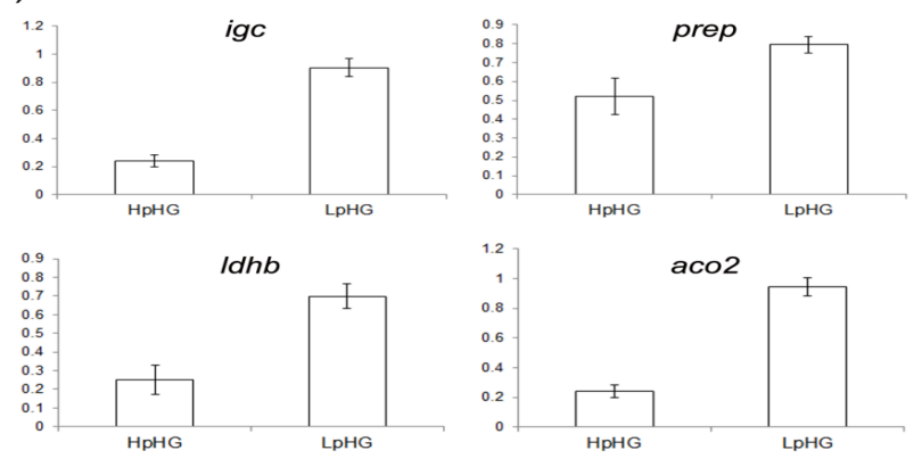

Figure 4. Relative expression levels quantified by reverse-transcriptase-mediated PCR analysis. (A) Individual

RT-PCR of gene such as igc (Ig lambda chain C region), prep (propyl endopeptidase), ldhb (lactate dehydrogenase-B) and aco2 (aconitate hydratase, mitochondrial) was presented as lane number 1-4 (HpHG); lane number 5-8 (LpHG). Beta-actin was used as internal standard expression marker. (B) The histograms representthe average of gene/ $\beta$-actinratios, measured with the ImageJ, densitometry software (http://rsbweb.nih.gov/ij/index.html) 


\section{Acknowledgements}

This work was supported by grants from the Priority Research Centers Program (2011-0022965) and Basic Science Research Program (2011-0024925) through the National Research Foundation of Korea (NRF) funded by the Ministry of Education, Science and Technology, the BioGreen 21 Program (20080401034059) of Rural Development Administration of Korea, and the Technology Development Program for Agriculture and Forestry (107091-5), Ministry for Food, Agriculture, Forestry and Fisheries, Republic of Korea. It was also financially supported by a Korea Basic Science Institute NAP grant (T32780) to J.S. Choi.

\section{References}

Ahsan, N., Lee, D. G., Alam, I., Kim, P. J., Lee, J. J., Ahn, Y. O., ... Lee, B. H. (2008). Comparative proteomic study of arsenic-induced differentially expressed proteins in rice roots reveals glutathione plays a central role during as stress. Proteomics, 8, 3561-3576.

Anderson, S., Aldana, S., Beggs, M., Birkey, J., Conquest, A., Conway, R., \& Zerr, S. (2007). Determination of Fat, Moisture, and Protein in Meat and Meat Products by Using the FOSS FoodScanTM Near-Infrared Spectrophotometer with FOSS Artificial Neural Network. J. AOAC Int., 90(4), 1073-1083.

Bee, G., Guex, G., \& Herzog, W. (2004). Free-range rearing of pigs during the winter: adaptations in muscle fiber characteristics and effects on adipose tissue composition and meat quality traits. J. Anim. Sci., 82(4), 1206-1218.

Cunningham, D., \& O'Connor, B. (1997). Proline specific peptidases. Biochim Biophysica Acta, 1343(2), 160-186.

Eprintsev, A., Semenova, E., \& Popov, V. (2002). Induction of aconitate hydratase in hepatocytes of starving rats. Biochemistry (Moscow), 67(7), 795-801.

Fischer, K. (2007). Drip loss in pork: influencing factors and relation to further meat quality traits. J. Anim. Breed. Genet., 124, 12-18.

Gondret, F., \& Lebret, B. (2002). Feeding intensity and dietary protein level affect adipocyte cellularity and lipogenic capacity of muscle homogenates in growing pigs, without modification of the expression of sterol regulatory element binding protein. J. Anim. Sci., 80(12), 3184-3193.

Hakimov, H., Walters, S., Wright, T., Meidinger, R., Verschoor, C., Gadish, M., ... Golovan, S. (2009). Application of iTRAQ to catalogue the skeletal muscle proteome in pigs and assessment of effects of gender and diet dephytinization. Proteomics, 9(16), 4000-4016.

Hocquette, J., Richardson, R., Prache, S., Medale, F., Duffy, G., \& Scollan, N. (2005). The future trends for research on quality and safety of animal products. Ital. J. Anim. Sci., 4(3s), 49.

Ishihama, Y., Oda, Y., Tabata, T., Sato, T., Nagasu, T., Rappsilber, J., \& Mann, M. (2005). Exponentially modified protein abundance index (emPAI) for estimation of absolute protein amount in proteomics by the number of sequenced peptides per protein. Mol. Cell. Proteomics, 4(9), 1265-1272.

Kauffman, R., Eikelenboom, G., Van der Wal, P., Engel, B., \& Zaar, M. (1986). A comparison of methods to estimate water-holding capacity in post-rigor porcine muscle. Meat Sci., 18(4), 307-322.

Kim, N., Cho, S., Lee, S., Park, H., Lee, C., Cho, Y., ... Park, E. (2008). Proteins in longissimus muscle of Korean native cattle and their relationship to meat quality. Meat Sci., 80(4), 1068-1073.

Kristensen, L., \& Purslow, P. (2001). The effect of ageing on the water-holding capacity of pork: role of cytoskeletal proteins. Meat Sci., 58(1), 17-23.

Lametsch, R., \& Bendixen, E. (2001). Proteome analysis applied to meat science: characterizing post mortem changes in porcine muscle. J. Agric. Food Chem., 49(10), 4531-4537.

Le Roy, P., Naveau, J., Elsen, J., \& Sellier, P. (1990). Evidence for a new major gene influencing meat quality in pigs. Genet. Res., 55(01), 33-40.

Liu, J., Damon, M., Guitton, N., Guisle, I., Ecolan, P., Vincent, A., ... Gondret, F. (2009). Differentially-expressed genes in pig Longissimus muscles with contrasting levels of fat, as identified by combined transcriptomic, reverse transcription PCR, and proteomic analyses. J. Agric. Food Chem., 57(9), 3808-3817.

McIntosh, D., Berman, M., \& Kench, J. (1977). Characteristics of sarcoplasmic reticulum from slowly glycolysing and from rapidly glycolysing pig skeletal muscle post mortem. Biochem. J., 166(3), 387-398. 
Medina, K., Strasser, A., \& Kincade, P. (2000). Estrogen influences the differentiation, proliferation, and survival of early B-lineage precursors. Blood, 95(6), 2059-2067.

Milan, D., Jeon, J., Looft, C., Amarger, V., Robic, A., Thelander, M., ... Rask, L. (2000). A mutation in PRKAG3 associated with excess glycogen content in pig skeletal muscle. Science, 288(5469), 1248-1251.

Offer, G., \& Knight, P. (1988). The structural basis of water-holding in meat. Part 1: General principles and water uptake in meat processing. Dev. Meat Sci., 4, 63-171.

Ponsuksili, S., Jonas, E., Murani, E., Phatsara, C., Srikanchai, T., Walz, C., ... Wimmers, K. (2008). Trait correlated expression combined with expression QTL analysis reveals biological pathways and candidate genes affecting water holding capacity of muscle. BMC genomics, 9(1), 367-380.

Slingsby, J., Dyson, P., Morley, B., Walport, M., \& Simpson, E. (1996). Mapping of the porcine immunoglobulin lambda gene, IGL, by fluorescence in situ hybridization (FISH) to chromosome 14q17-q21. Mammal. Genom., 7(4), 326.

Wang, J., Xue, Y., Feng, X., Li, X., Wang, H., Li, W., ... Zhou, P. (2004). An analysis of the proteomic profile for Thermoanaerobacter tengcongensis under optimal culture conditions. Proteomics, 4(1), 136-150.

Warner, R., Kauffman, R., \& Greaser, M. (1997). Muscle protein changes post mortem in relation to pork quality traits. Meat Sci., 45(3), 339-352.

Wheeler, T., Shackelford, S., \& Koohmaraie, M. (2000). Relationship of beef longissimus tenderness classes to tenderness of gluteus medius, semimembranosus, and biceps femoris. J. Anim. Sci., 78(11), 2856-2861.

Xu, Y., Jin, M., Wang, L., Zhang, A., Zuo, B., Xu, D., ... Li, F. (2009). Differential proteome analysis of porcine skeletal muscles between Meishan and Large White. J. Anim. Sci., 87(8), 2519-2527. 